Leverhulme professor of physical chemistry in the University of Bristol, lately ohief superintendent, Armament Research Department, Ministry of Supply ; J. McD. R. Greig, director of Moredun Institute, Animal Diseases Research Association; H. Grinsted, director of technical research and development, Ministry of Aircraft Production; C. E. Horton, chief scientist, Admiralty Signal Establishment; Dr. W. B. Lewis, for services as superintendent, Telecommunications Research Establishment, Ministry of Aircraft Production; Prof. R. P. Linstead, director of the Chemical Research Laboratory, Department of Scientific and Industrial Research. for work in the Foreign Office; Dr. A. Parker, director of fuel research, Department of Scientific and Industrial Research; Prof. E. S. Pearson, professor of statistics at University College, London, and associate member of the Ordnance Board; Dr. H. Schofield, principal of Loughborough College; Prof. L. Dudley Stamp, professor of geography in the University of London (London School of Economics and Political Science), chief adviser on rural land utilization, Ministry of Agriculture; Prof. W. N. Thomas, professor of engineering in the University of Wales (University College, Cardiff); Prof. R. Whiddington, Cavendish professor of physics in the University of Leeds, for services to Government Departments.

I.S.O. : R. J. O'Keefe, superintending forestry officer, Department of Natural Resources, Newfoundland.

\section{International Control of Atomic Energy}

THe Atomic Energy Commission of the United Nations Organisation met for the first time on June 14. Some idea of the problems and suggestions which the Commission will have under its consideration are dealt with in the leading article in this issue of Nature (p. 817); while elsewhere (p. 826), Sir George Thomson discusses the views put forward some time ago at a meeting of the American Philosophical Society, when political, social and moral issues, as well as the more purely physical aspects, were dealt with. Up to the time of writing, the most noteworthy event of the Atomic Energy Commission's meeting had been the presentation by Mr. Bernard Baruch of American proposals for the control of nuclear energy. These were largely based on the report of the Lilienthal Board, the central feature of which is the division of activities in the field of nuclear research into two categories, 'dangerous', as leading to the production of atomic bombs, and 'safe', which includes work concerned with the development of peace-time applications of atomic energy. The suggested Atomic Development Authority, which would conduct research on 'dangerous' developments and provide material for the use of those concerned with academic research and civilian utilization, is accepted by Mr. Baruch, and its significance enhanced by the proposal that its decisions should not be subject to the need for a unanimous vote. The Authority should be the world's leader in all that pertains to atomic knowledge and development. The United States, he said, is prepared to yield to such an international body, step by step as successive stages of control are reached, the present national control of atomic activities which it exerts. In Great Britain, the first annual general meeting of the Atomic Scientists' Association was held on June 15, and at its conclusion it was stated that the Association regards the American proposals with much satisfaction.

\section{Chemistry at Reading: Prof. E. A. Guggenheim, F.R.S.}

Dr. E. A. Guggenherm, whose appointment to the chair of chemistry at the University of Reading in succession to Prof. H. Bassett has recently been announced, is well known for his contributions to thermodynamics and statistical mechanics and for his original work in the borderland lying between physical chemistry and theoretical physics. After a period of training with R. H. Fowler at Cambridge, Dr. Guggenheim spent some six years at Copenhagen studying reaction kinetics under Brönsted and electrochemistry under Bjerrum; in 1932 he went to California as visiting professor at Stanford University. Returning to England in 1933, he was appointed temporary lecturer at the University of Reading, and two years later, lecturer at University College, London. In 1938 he joined Sir Alfred Egerton at the Imperial College of Science and Technology as lecturer in chemical thermodynamics. During 1939-44 he was engaged almost entirely upon war-work at the Admiralty, first in the Department of Mines and Torpedoes and later in the Department of Miscellaneous Weapons. In 1944 he was transferred to the Anglo-Canadian Atomic Energy Laboratory in Montreal, where he continued until 1946. Dr. Guggenheim, who was elected a fellow of the Royal Society this year, is the author of a large number of papers dealing with various aspects of reaction kineties, the thermodynamics of mixtures, solutions, electrolytes, super-lattices and surfaces and of the electromotive force of cells with liquidliquid junctions. $\mathrm{He}$ is also author of a standard work on classical thermodynamics, and joint author, with the late R. H. Fowler, of the well-known treatise on "Statistical Thermodynamics".

Exhibition of Gold, Silver and Platinum Products

THE first impression one receives at the exhibition arranged by Messrs. Johnson, Matthey \& Co., Ltd., at Dorland Hall, Lower Regent Street, London (June 13-26, admission by ticket from the Company, 73-83 Hatton Garden, London, E.C.1), is the extremely wide range of application of the products of this company and its associates. Besides the production of gold, silver, platinum and similar metals in pure form, there are numerous specialized products, from well-known laboratory ware, thermocouples and chemical plant to electrical contacts, catalysts, electrical measuring instruments, electronic equipment, brazing alloys, ceramic colours and alloys for manufacturing jewellers and dentists, to mention only a few. The less well-known ceramic side of Johnson, Matthey and Co.'s interests is well represented by a display of pottery, china and glassware illustrating the extensive range of brilliant coloured enamels and lustres available, as well as the use of platinum and gold. The jewellery section does not exhibit finished jewellery so much as the special rolled gold wire, gold and silver alloys in various special forms for the manufacturing jeweller, platinum and palladium in jewellery form and special salts and anodes for plating with these metals. The dental, surgical and optical division displays a range of dental gold alloys in wire, castings and inlay form, radium equipment for medical use and a variety of rolled gold shapes for the spectacle manufacturer.

The exhibition also shows the products of Mallory Metallurgical Products, Ltd., one of the associated companies of Johnson, Matthey and Co. These in. clude high-strength, high-conductivity copper alloys 
for switchgears and electrical furnaces, berylliumcopper alloys for springs and pressure-responsive elements, spot-welding electrodes, bimetal contacts and circuit breaker contacts. Demonstrations are given of brazing with the various low-temperature silver brazing alloys, 'Easy-flo', 'Argo-flo', 'Sil-fos' and 'Silbralloy', by induction-, resistance-, furnaceand gas-torch heating. The amazing rapidity with which 'Easy-flo' spreads through a joint in a copper assembly has to be seen to be believed. The whole exhibition bears an air of the care and precision with which the products, so often used as standards of measurement, are made.

\section{Scient fic Exports (Great Britain), Ltd.}

LEADING manufacturers of scientific and surgical equipment in Great Britain have announced the formation of Scientific Exports (Great Britain), Ltd., a new export company. Their plans include groupselling in overseas markets by a wide development of the existing agency organisation of individual members; new agents are also being appointed in territories where member companies had no previous export business. The Company has been formed with the co-operation of the Export Promotion Department of the Board of Trade. The technical knowledge, scientific skill and wide experience of the constituent members will be at the new Company's disposal, and Dominion and foreign customers can therefore bring their requirements and problems to a single source (the Company's overseas agent). The foundation of the new Company has been laid by the following well-known firms: Allen and Hanburys, Ltd.; Baird and Tatlock (London), Ltd.; W. Edwards and Co. (London), Ltd. ; Adam Hilger, Ltd. ; Hopkin and Williams, Ltd.; W. Watson and Sons, Ltd. ; E. R. Watts and Son, Ltd. Between them, these companies offer a wide range of equipment, which includes surgical instruments and sutures, general laboratory equipment, high-vacuum pumps and equipment, spectroscopic and other optical instruments, fine chemicals, microscopes of all types, and surveying instruments. Inquiries should be sent to : Scientific Exports (Great Britain), Ltd., Buckingham House, Buckingham Street, Adelphi, London, W.C.2.

\section{World Economy}

A pamphlet "Money and Banking", issued by the Joint Council of Monetary and Economic Research, 20 Buckingham Street, London, W.C.2 (Pp. 36. 1s. 6d.) as part of a wider study of the functioning of our economic system made by the Engineers' Study Group on Economics, one of the supporting bodies of the Joint Council, attempts to give a picture of the way in which legal tender and bank deposits are produced. After describing the banking system in Great Britain, it discusses the gold standard and outlines briefly the vicissitudes of the economic and financial development of Britain since 1914, down to the introduction of the Bank of England Bill in October 1945. The effect of the Second World War, 1939-45, is dismissed rather summarily, and the absence of any mention of the financial and monetary agreements at Bretton Woods makes the pamphlet necessarily incomplete.

The lattor omission is repaired by E. Charles in a rather colourless pamphlet "Freedom from Want : the International Aspect" published by the Royal Institute of International Affairs (Pp. 60. 1s. net). Citing first the fifth article of the Atlantic Charter, Mr. Charles outlines the main features of collaboration in a world economy, sketching the structure of a system of international economic collaboration and an approach to the problems with which it must deal. A trend towards a higher degree of central control and planning than existed before the War is recognized, and the view is accepted that the main factors affecting the level of employment are broadly within the control of Government. Any international system proposed must be compatible with the national organisation of full employment policies, and the argument for foreign trade is an argument for efficient production. The choice lies between regionalism based on bilateral bargaining and the reconstruction of a world economy in which international trade would be organised on multilateral lines. Mr. Charles then deals with questions of currency and full employment and outlines the implications of the International Monetary Fund of the Bretton Woods Agreement. The consequences of the Hot Springs Conference on Food and Agriculture and the economic aspects of the work of the Food and Agricultupe Organisation are next con. sidered, followed by the questions of commodity controls and the conditions for a constructive policy, foreign trade, and the functions of an international trade commission and international investment. The proposals for an international bank are outlined, and finally Mr. Charles glances briefly at the place and functions of the International Labour Organisation and the limits of collaboration. The pamphlet gives a convenient review of the present position and of the factors to which we must have regard in that gradual development through which alone a satis. factory system of economic collaboration will be ashieved.

\section{Amateur Entomologists' Society}

THE Amateur Entomologists' Society, which exists to stimulate and broaden the interests of those who take up entomology as a hobby, was founded in 1935. To-day its members number nearly five hundred. Its publications specialize in matters of practical value to the amateur. We have received the two most recent issues of the Amateur Entom. ologist, the Society's principal journal. The annual issue for 1943 is entitled "The Hymenopterist's Handbook", which has been written by a panel of specialists in that order of insects. It contains a good deal of useful information regarding the study and identification of its numerous species. The 1944 issue of that same journal is a similar kind of guide to the study of the Odonata, Heteroptera, mosquitoes and other of the smaller groups of insects. Anyone interested in the work and aims of the Society should communicate with the honorary secretary, Miss Phyllis Rogers, 91 Middle Lane, London, N.8. The membership subscription, it may be added, is only 5s. a year.

\section{Books on Medicine, Surgery and the Occult Sciences}

A RECENT catalogue (No. 636) issued by Messrs. Bernard Quaritch, Ltd., includes, among other subjects, books on medicine and surgery and on the occult sciences. There are 148 choice items in medicine and surgery, and 319 on the occult sciences. Among the medical books the following are worthy of special mention: there is a copy of "Tractatus de virtutibus herbarum" of Arnold of Vallanova, published at Vicenza in 1491. There is also a superb copy of the "Scriptores Rei Rusticæ", printed in 